\title{
Study on the Intercultural Education in College English Teaching*
}

\author{
Zhijuan Sui \\ Shandong Jiaotong University, China
}

\begin{abstract}
Learning a foreign culture means getting in touch with a new culture. Intercultural education is gaining more and more attention in college English teaching. Cultural teaching in cross-cultural background involves more than the introduction of a target culture, but rather the emphasis of both the source culture and target culture. To fulfill the responsibility of spreading excellent Chinese culture to the world, both the foreign language learners and teachers should develop more versatile cross-cultural perspectives.
\end{abstract}

Index Terms —English teaching, Chinese culture, western culture, measures

\section{INTRODUCTION}

With the advancement of globalization, people from all over the world are getting more and more involved with each other. Being the language most widely used in political, economical and cultural exchanges all around the world, English is becoming more dominant than ever before. Since English was first introduced into Chinese colleges and universities in late 1970's, it's been going through many major reforms. We used to focus on teaching new words and grammatical rules, and later moved on to communicative teaching, and then student-centered multimedia classroom teaching. But the fact is evident that for tons of Chinese English learners, English learning is like a nightmare. Normally Chinese students begin to study English as early as primary school, but after more than ten years of hard study, it seems that they are going nowhere except that some of them can get decent scores in CET-4/6. They are normally bad at listening and speaking, intimidated to communicate with English-speaking people. It's hard for them to use the language as a work language. Nowadays English experts, teachers and learners are reflecting on this time-consuming and low efficiency phenomenon. Under this background people begin to notice the lack of intercultural education in college English teaching has greatly undermined the effects of college English teaching.

\section{Problems IN COLlege English Teaching}

There are some problems in college English teaching that we should be aware of.

\section{A. Cultural Factors Presented But Neglected in Textbooks}

In July 2007, Ministry of Education put forward The Basic Requirements of College English Teaching to guide the college English teaching. According to the requirements, college English should be guided by foreign languages teaching theories, focus on English language knowledge, application skills, intercultural communications and study strategies and make use of multiple teaching models and methods. The aim of college English teaching is to cultivate the comprehensive application abilities of the students especially the listening and speaking abilities so that they can communicate with English in their study, work or social life, and at the same time enhance their self-study abilities, improve their cultural qualities to adapt to the requirements of social development and international exchange.

New Horizon English published by Foreign Language Teaching and Research Press is edited according to the requirements. It is a series of English textbooks being used by colleges and universities all over the country. It has four levels intended to be used for two years. In this book series, articles concerning America are very dominant. From these articles we can find that Chinese culture and American culture have many differences in values, beliefs, religions, customs, norms, thinking styles, etc. If these cultural factors are neglected, students will be confused while studying and lots of cultural information cannot be conveyed to students. The following are some examples of cultural factors that should be introduced to the students while teaching.

Chinese people and western people also have different likes and dislikes. In Unit 2, Book One, the article "Deep Concern" presents the readers a picture of generation gap in an ordinary American family. The teenage girl Sandy began her weekday with rock and roll music which upset her father a lot, wore makeup and torn jeans which made her mother worried and rushed to catch the school bus without having a decent breakfast. All these descriptions can surprise our students. For Chinese teenagers, weekday life is more like a routine, starting with the nutritious breakfast prepared carefully by parents, going to school clean and clear usually in uniforms because makeup is totally forbidden for middle

\footnotetext{
* Supported by Scientific Research Program of Shandong Jiaotong University (No. R201010) and Social Science Planning Research Projects of Shandong Province (NO. 12CWJZ03).
} 
and high school students, not to mention tattoos and piercings. If we don't supply the students with the background cultural information, they will totally feel at loss.

"Rich Meeting His Future Mother-in-law" in Unit 3, Book Two, is a very funny story about a Chinese girl (the author) bringing her American boyfriend Rich home to have dinner with her family. It's typical Chinese culture for future parents in law to prepare a wonderful meal to show that they are taking someone seriously. The author is kind of happy when the mother is busy in the kitchen. But things didn't go well because of the cultural conflicts. When being praised, Chinese people tend to be modest by denying the compliments. This often causes confusion because in American culture when being praised, American people tend to be happy and thankful. It's also Chinese culture to show modesty by self-denial. When the author's mother served her best dish, she complained about not being good enough because of the lack of salty flavor, which in Chinese culture is a sign for the guests and family members to praise the dish as the best one they have ever tried. But Rich believed the story and began to pour plenty of sauce right in front of the mother's shocking face, which in turn ruined the first meeting. This is a very typical example of the cultural differences and cultural conflicts.

"Graceful Hands" in Unit 5, Book Three, is about a story between the author (a doctor) and Mrs. Clark who is leaving the world. In order to save her family the painful moments of watching her dying, she sent all of them home and let the author stay around. In this process, her graceful hands and beautiful mind impressed the author very much. But it is really difficult for Chinese students who grow up in traditional Chinese culture to understand a story like that. In Chinese culture, when a significant family member is about to leave the world, the whole family will stay around to show their love and care. If one couldn't be there for some reason, it will be a great regret for everyone. Things are rather different in the United States. People there are more self-centered. The relationships between children and parents are more concerned with emotions instead of obligations. Parents take the responsibility of taking care of the children before they grow up, but children don't take the responsibility of taking care of their parents when they are old. When people get old, they will go to senior people's home to spend the rest of their lives. Both the parents and children don't think children should take the responsibility. Only after having this information can our students have a better understanding of the empathy between the two human beings?

"Choose to Be Alone On Purpose" in Unit 5, Book Four is another example of differences in values between Chinese culture and American culture. In American society lots of people choose to live alone, and this is even called national disease as well as characteristics of American heroes. Solitary hunters and explorers are easily found in literature. In Chinese culture, though poets and philosophers also seek for solitude, for most people choosing to be alone or having to live alone is pathetic. The reason behind that is in China people value collectivism while in America people value individualism. Chinese students are taught from very young age that public interests and personal interests are intermingling. Public interests should be on the top priority, and everyone should always be a part of the group, rely on the group and devote to the group in order to achieve personal interests. But American students are encouraged from very young age that they should always be themselves, pursue their personal freedom and right, and live the life as they wish. No one should interfere and limit others' lives. This also explains why Americans move a lot, while Chinese people seldom move. This article gives the students a good opportunity to understand the fact that different people on the earth are choosing different ways to live.

\section{B. Chinese Culture Aphasia}

When we emphasize the introduction of western cultures in our college English teaching, we should always bear in our mind that our purpose of learning a foreign language is not only about the foreign language and culture. Instead, it's more about intercultural communications. (Hymes, 1971) Spreading our excellent Chinese culture and helping the world understand more about China is more significant.

In China, culture education research in English teaching began in 1980's. In this stage, experts mainly focused on the relationship between culture and language, and stressed the importance of culture introduction in English teaching. In the following 10 years, the focus of the research shifted to how to systematically introduce target language culture and the principles of culture introduction. Teaching syllabus, textbooks and teaching arrangements were modified in this stage. Since 1990's, with the advancement of language and culture research, culture teaching research witnessed a dramatic change. Researchers began to realize that mother tongue culture and target language culture shouldn't be separated. Students should be encouraged to understand western culture, and more importantly they should be aware of their responsibilities to appreciate and spread Chinese culture. Some experts and researcher made surveys about present situations of mother tongue culture learning, the conclusion is that Chinese students know very little about mother tongue culture.

Under this background, Professor Congcong from Nanjing University first proposed the concept of Chinese culture aphasia in 2000. Aphasia is a medical terminology, which originally used to refer to the partial or total loss of the ability of expressing ideas and the ability of verbal and written understanding because of the brain damage caused by injuries or diseases. In 1990s, literature critics began to criticize the invasion of western literature thinking and the loss of Chinese ancient literature thinking caused Chinese culture aphasia. Professor Congcong is the first person who has proposed the concept of Chinese culture aphasia in foreign languages teaching. He found that many young Chinese scholars who have a good command of English cannot express Chinese culture and cannot represent the style of the deep and independent Chinese culture when they communicate with westerners. When our foreign peers are eager to 
know Confucianism or Taoism, we are at a loss, having nothing to share. (Cong, 2000) If our English teachers and scholars are having problems like this, it's not difficult to understand the difficulties our English learners are faced with. After many years of English learning, our students don't know how to answer simple questions like "What do you usually have for your breakfast?'The reason is that they don't know how to say "bean milk, steamed bread or fried dough". But on the other hand they know almost everything about western food, fried chicken, hamburgers, pizza, etc. Some of the students have very rich knowledge of western culture: they watch American movies and TV series, watch NBA games and sing RAPs. But when it comes to Chinese culture, they may find that they are really incapable of introducing their own culture. Very few students can explain in English the typical Chinese cultures like Chinese holidays, herbal medicines, acupuncture, Beijing Opera, Chinese cuisine .... The reason is that they know little about Chinese culture, they cannot even express the cultural connotations in Chinese not to mention English. Chinese culture aphasia is a very common phenomenon in Chinese language learners: they lack the knowledge of mother tongue culture and the ability to express Chinese culture in English. The phenomenon exposes the defects of college English education in China.

\section{Lagging behind Both in Teaching and Learning}

The phenomenon of Chinese culture aphasia is caused by many reasons, such as educational and teaching concepts, teaching strategy and method, limitations of learners' ability, etc. This phenomenon reflects the lagging behind both in teaching and learning.

Most English teachers grow up in examination-oriented educational system and they themselves have limited knowledge of both western culture and Chinese culture. They gain their knowledge of western culture mainly from textbooks and very few of them ever go or study abroad, so it's reasonably difficult for them to present a true picture of western culture to their students. Meanwhile the lack of cultural awareness in English teachers unavoidably affects the cultivation of the students' cultural awareness. In most colleges and universities, English is still taught as a foreign language (TEFL), the main purpose of which is to cultivate students' communicative skill.

Most of the English teachers have rather tight schedules, therefore they don't have enough time and energy to read English newspapers, watch English movies or get access to modern media to collect first-hand and fresh information about western culture. In the long run, this will severely undermine the quality of English teaching. With the economic globalization and the broadening of the international communication, it's evident that the traditional English teaching cannot satisfy the need of rapidly developing world. As a lingua franca, English should be taught an international language (TEIL) to make sure that people from different countries and different cultures can communicate with English. But in China English teaching has been focusing on grammar and structure analysis, and English teachers mainly teach vocabulary and grammatical rules to improve the students' linguistic ability and to make sure that students can have correct grammars, good pronunciations and certain amount of vocabulary. CET-4/6, as one of the most influential exams in China plays a very negative role because of its language orientation. This exam was intended for college students who have finished two years of college English study to make sure that they have fulfilled the course requirements. So this exam was designed as a course test. But what happened is that the whole society has increasingly been paying overdue attention to this exam. Enterprises and institutions ask for CET- 4/6 certificates when they enroll new employees, thus changing the real purpose of the test, and many colleges and universities use the CET- 4/6 scores to evaluate the teachers' as well as students' performances. Even after the reform of the test in recent years, the progress is still rather slow. This in turn fostered the exam-oriented English teaching in China. Very few teachers would try to bring culture into the classrooms because this is not included in the test.

As to the students, they are inevitably influenced by the language orientation test and the test orientation teaching. The classroom teaching itself loses its charm because the teaching has been the same in students' ten years of language learning, and the enthusiasm of the students is fading gradually. In order to have a decent job in the future, they have to take CET-4/6, which makes situation even worse. As young adult, they have the basic judgment that language learning should be linked with communication, and they have the strong desire to use the language as a tool for both academic and communicative purposes. But the fact is they have no alternative but to compromise to learn English for exams. Therefore, they intentionally or unintentionally neglect the learning of cultural factors in English. They know the romance of Valentine's Day, but they don't know the origin of it; they know Christmas and Thanksgiving Day, but they know little about the values and customs concerning the festival; they love Hollywood movies and American TV series, but they don't bother to probe into the beliefs and norms of western people. As to Chinese culture, they are showing less and less interests. They have no fun in celebrating Chinese traditional festivals, read fewer and fewer Chinese classics, and they seem to totally ignore the necessity to continue the learning of Chinese culture in learning English. In recent years, more and more westerners start to pay attention to Chinese culture. College students today in fact should take double responsibilities: on the one hand, they need to learn about western cultures to communicate cross culturally, and on the other hand, they need to spread Chinese cultures with the international language English.

\section{REFLECTIONS AND MEASURES}

To solve the problems mentioned above, both the learners and teachers should reflect and take appropriate measures.

A. Cultivating High Quality Teachers 
We are living in a world where cultural blending and conflicting are unavoidable. Intercultural awareness and ability are basic qualities of modern people. (Byram, 1989) English teachers should undoubtedly take the responsibility to cultivate the English learners' ability of cultural communications because of their bilingual and bicultural backgrounds. To fulfill the task, English teachers should have the following qualities.

Firstly, right intercultural attitude is the basic requirement. English teachers should treat the foreign culture and home culture equally. English is not only used by native English speakers, and it is a virtually international language. We can not only communicate with native English speakers, but also any person from a different culture who can speak English. Both cultural centralism and hegemonism can be harmful. Cultural differences are reasonable existence, and the teachers should take an objective and lenient attitude. There are weaknesses and strengths in each culture. There is no so called superior culture; its only different people live their lives in different ways. (Kramsch, 1993) Being sensitive and adaptive to the differences and being ready to embrace the excellent factors to nourish native culture are crucial for qualified English teachers.

Secondly, they should broaden their intercultural horizon. Intercultural communication is based on the understanding of different cultures. This understanding of foreign cultures is determined by whether we can fully respect a different culture and develop multi-culture thinking. Most Chinese English teachers grow up in Chinese cultural background, lack of foreign cultural background, and this in some degree hinder the correct expressions of English culture. In the meantime, they worship western cultures more than home culture, and this stops them work hard to explore the differences and similarities between English culture and Chinese culture. In order to broaden the intercultural horizon, the teachers should work equally hard to know both cultures to meet the need of intercultural education.

Thirdly, English teachers should develop excellent intercultural teaching abilities. This ability reflects the teachers' professional level, and guarantees the possibility of cultural education. Professor Tubei used to say that the greatest challenge for English teachers is not to teach language plus explanation of cultural points or to start a culture course, but to blend language and culture in teaching. (Tubei, 1994)Therefore, timing is very important. Whenever there are conflicts between English and Chinese cultures, teachers should step in to compare and identify. Also, the teachers should take different perspectives to analyze cultural factors. In fact, at initial stage they should work more from Chinese culture perspective, since this is the cognitive frame of both Chinese students and teachers. The introduction of a foreign culture must be gradual, natural, enlightening and relative, and it should by no means be focused, imposing and isolated.

\section{B. Reforming English Teaching Models and Methods}

Influenced by traditional English teaching theories and methods, cultural education remains a weak part. In order to change the present situation, the reforming is necessary, and the introduction of Chinese culture into English classes should be an indispensable part of the teaching.

Culture teaching can take the forms of researches, lectures and practice. Research study asks the students choose a cultural topic that interests them from their academic sphere or real life, and the students then independently collect information, make surveys, communicate with people so as to gain progress in knowledge, skills and emotions. This method can motivate the learners' curiosity and cultivate their creative thinking.

The teachers can also organize the cultural phenomena and facts into some keynotes, and then lecture in classes so that the students can learn culture in a systematic way. Of course this is totally different from the traditional lecturing in that it stresses the students being the center, and the teachers only instruct the students to construct the knowledge by themselves.

Learning by doing should also be encouraged. Interactions among students can help them actively create multicultural environment and change their stereotypes of cultural orientations. The forms of interactions can be various: cultural performances, culture festivals, cultural forums, online cultural chatting rooms, etc.

Besides making use of whatever cultural teaching and learning models and methods, both the teachers and learners should always bear Chinese culture in mind. Elective courses of Chinese culture should be included in college English system, and these courses should be delivered in English. Students should learn to great extent to appreciate and spread Chinese history, philosophy, literature, and customs in English.

\section{Creating Cultural Environment}

We are learning and teaching English in a non-English environment. It is almost impossible to get systematic knowledge of English and American cultures. Classroom time is so limited. Yet we can make good use of mass media, like movies, TV series, newspapers and magazine to bridge the gaps and create cultural environment. Movies and TV series are especially useful in making up the lack of learning environment. The movies and TV series themselves have the characteristics of combining nature and society, culture and history, religion and ethics, ideal and reality, which covers almost every aspect of culture. Furthermore, they enjoy a variety of types, from legends to epics, from science fictions to war stories, which provide English teaching with rich material. According to language learning theories, language learning demands sufficient input, and this input must be of high quality. Language in movies and TV series are native and authentic, the settings of communications are real and natural, and this is the real high quality input. When the students watch the movies and TV series, they can experience both the language and the culture, and they will come into contact with a large number of most frequently used words and expressions and thus realize the true meaning 
of learning a foreign language. Of cause, the selection of the movies and TV series is a major task for teachers. They cannot just randomly show them to the students. There are many negative factors in western culture, and young students are not mature enough to make judgments on themselves. There are inappropriate scenes like violence and sex, so the teachers must take the responsibility to choose movies or episodes suitable for classroom settings.

Another effective way to create cultural environment is to invite more foreign teachers to English teaching classrooms. With the advancement of international communications, it becomes easier for colleges and universities to hire qualified foreign teachers to take part in college English teaching and the opening and rapidly developing China is also a great attraction to foreign teachers. Let's take Shandong Jiaotong University for example. Every year, we recruit 8 foreign teachers from English speaking countries to teach the students listening and speaking courses. The students can not only learn from them in classrooms and they keep in contact even out of classrooms. The first hand information and experiences of the foreign teacher really benefit the students as well as Chinese English teachers.

\section{CONCLUSION}

Culture is one of the key words of the new century, and the world civilization is developing in the process of different cultures blending and conflicting. Intercultural communications give us opportunities to broaden our horizons and enjoy the relevant achievements. How to improve the students' intercultural abilities has become and will remain a significant part of college English teaching. Both the teachers and students should take their responsibilities to meet the challenge of this new era.

\section{REFERENCES}

[1] Byram M. (1989). Culture Studies in Foreign Language Education. Clevedon: Multilingual Matters.

[2] Claire Kramsch. (1993). Context and Culture in Language Teaching. Oxford: Oxford University Press.

[3] Cong Cong. (2000). Guangming Daily: Chinese culture aphasia: Defects of English Teaching in China.

[4] The Basic Requirements of College English Teaching. (2007). Shanghai: Shanghai Foreign Language Education Press.

[5] Dell Hymes. (1971). Communicative Competence. Philadelphia: University of Pennsylvania Press.

[6] Tubei. (1994). Language Teaching and Research: Multi-cultures of US and Their Impacts on Foreign Language Teaching.

Zhijuan Sui was born in Gaomi, China in 1971. She received her master degree in linguistics and literature from Shandong Normal University, China in 2003.

She is currently an associate professor in the School of Foreign Languages, Shandong Jiaotong University, Ji'nan, China. Her research interests include intercultural communications and foreign language teaching. 